\title{
PENINGKATKAN HARGA DIRI PADA KLIEN GAGAL GINJAL KRONIK MELALUI COGNITIVE BEHAVIOR THERAPY (CBT)
}

\author{
Tri Setyaningsih ${ }^{12^{*}}$, Mustikasari $^{3}$, Tuti Nuraini ${ }^{3}$ \\ 1. Akademi Keperawatan Husada, Jakarta 10730, Indonesia \\ 2. Program Studi Magister Fakultas Ilmu Keperawatan Universitas Indonesia, Depok 16424, Indonesia \\ 3. Fakultas Ilmu Keperawatan Universitas Indonesia, Depok 16424, Indonesia \\ *Email: trisetya_762@yahoo.co.id
}

\begin{abstract}
Abstrak
Penelitian ini bertujuan untuk menguraikan tentang pengaruh Cognitif Behavior Therapy $(C B T)$ terhadap perubahan harga diri klien Gagal Ginjal Kronik (GGK) di unit hemodialisa RS H Jakarta. Penelitian dilakukan menggunakan pendekatan kuantitatif, dengan metode quasi eksperimen pre-post test without control group. Penelitian dilakukan terhadap 27 responden (klien GGK) yang sedang menjalani hemodialisis. Hasil penelitian menunjukkan bahwa terdapat perubahan harga diri baik dari aspek kognitif maupun perilaku yang signifikan sesudah dilakukan intervensi $C B T(\mathrm{p}=0,000 ; \alpha=0,05)$. Rekomendasi hasil penelitian $C B T$ dijadikan salah satu terapi spesialis bagi klien GGK di unit hemodialisa pada khususnya dan klien yang mengalami gangguan psikososial pada umumnya.
\end{abstract}

Kata kunci: cognitive behavior therapy (CBT), harga diri rendah, kognitif, perilaku

\begin{abstract}
The aims of this study is to describe the effects of cognitive Behavior Therapy (CBT) to changes in self-esteem of patients with Chronic Kidney Disease (CKD) in hemodialysis units H Hospital Jakarta. The study was conducted using a quantitative approach, with the method quasi experimental pre-post test without control group. The study was conducted on 27 respondents (CKD patients) who are undergoing hemodialysis. The results showed that there were changes in self-esteem in terms of both cognitive and behavioral intervention that significantly after CBT $(p=0,000 ; \alpha=0,05)$. Recommended studies of CBT is can be as one specialist treatments for patients CKD in Haemodialysis Unit particularly and in patients with psychosocial disturbances in generally.
\end{abstract}

Keywords: cognitive behavior therapy (CBT), low self-esteem, cognitive, behavioral

\section{Pendahuluan}

Gagal ginjal kronik (GGK) atau penyakit ginjal tahap akhir (PGTA), merupakan salah satu penyakit yang menjadi masalah besar di dunia. Selain sulit disembuhkan karena bersifat irreversible (tidak bisa pulih kembali), seperti kebanyakan orang yang menderita penyakit terminal, seseorang yang divonis menderita GGK juga akan mengalami kondisi yang sama. Klien akan selalu dibayangi dekatnya masa kematian, merasa tidak dapat lagi mengatur diri sendiri, dan harus bergantung pada orang lain. Kondisi demikian tentu saja akan menimbulkan perubahan dan ketidakseimbangan di dalam aspek kehidupan klien. Perilaku yang sering ditunjukkan yaitu, mudah tersinggung dan merasa tidak berguna.
Menurut Levey dan Coresh (2002) menyatakan bahwa di Amerika Serikat setiap tahun diperkirakan berjumlah sekitar 20 juta orang dewasa menderita penyakit gagal ginjal kronik dan hampir separuhnya menderita gagal ginjal moderat (sedang) yang memerlukan pelayanan hemodialisis. Sedangkan berdasarkan data, angka kejadian gagal ginjal di Indonesia setiap 1.000.000 penduduk didapatkan antara 200 - 300 klien baru dengan gagal ginjal kronik (DepKes RI, 2004).

Berdasarkan data tersebut di atas, maka penderita gagal ginjal terus meningkat setiap tahunnya. Jika klien gagal ginjal tidak ditangani dengan baik maka meningkat pula klien dengan gagal ginjal kronis dan dengan penyakit kronis meningkat pula berbagai permasalah psikososial. 
Klien dengan gagal ginjal kronis (GGK) akan mengalami perubahan biopsikososiospiritual dalam kehidupannya. Perubahan biologis (fisik), seperti harus mengatur pola-pola hudupnya yaitu pola makan, pola minum (intake cairan), pola aktivitas dan pola istirahat, semua ini harus seimbang, tidak boleh berlebihan atau disesuaikan dengan kemampuan fisiknya (Lumenta, 2005). Perubahan psikologis, termasuk didalamnya ialah kecemasan, ancaman akan kematian, perasaan bersalah karena terus bergantung pada orang lain, merasa tidak berguna, dan tidak berharga (Roesli, 2006).

Perubahan sosial, klien menjadi malas untuk berhubungan dengan orang lain, biasanya muncul adalah cenderung menarik diri dari lingkungan sosialnya (Purwanto, 2004). Pada perubahan spiritual, klien cenderung menyalahkan Tuhan, menganggap-Nya tidak adil karena memberikan hukuman pada dirinya sehingga malas untuk menjalankan ibadah.

Tindakan medis untuk mengatasi klien dengan gagal ginjal kronis sudah dapat dilakukan di Indonesia. Namun, hal yang masih menjadi sebuah masalah adalah meningkatkan kualitas hidup klien yang menjalani hemodialisa sehingga klien tetap dapat produktif, sebab banyak klien gagal ginjal kronis menjadi satu-satunya tulang punggung keluarga (Suhud, 2005). Cuci darah (hemodialisis) yang mahal dan harus dilakukan seumur hidup menjadikan gagal ginjal kronis (GGK) sebagai The Silent Killer (Siregar, 2001).

Dampak sosial yang dirasakan sehubungan dengan rangkaian perawatan medis yang harus diikuti, antara lain; individu akan kehilangan hal-hal vital dalam hidup, seperti pekerjaan dan kehilangan kebebasan pribadi. Sedang dampak psikologis tampak dari sikap individu yang tidak dapat menerima begitu saja, bahwa klien harus menjalani terapi hemodialisis seumur hidupnya. Mereka merasa sudah cacat dan akan menderita sepanjang hidupnya, merasa bahwa tidak ada lagi cita-cita dan harapan yang dapat dicapai, serta merasa tidak dapat lagi melaksanakan berbagai kegiatan seperti yang selama ini dijalani (Feldman, 1989).

Proses cuci darah yang harus dijalani 2 - 3 kali seminggu membuat klien merasa bahwa sebagian besar waktu yang mereka miliki dilalui di rumah sakit. Perasaan kecewa dan putus asa terhadap hidupnya membuat klien GGK mengalami depresi (Roesli, 2006). Penelitian yang dilakukan oleh Abram (1987, dalam Levey \& Coresh, 2002) mengenai tingkat penerimaan klien GGK terhadap vonis hemodialisis menunjukkan bahwa klien baru dapat menerima kenyataan harus cuci darah setelah klien berada di ambang kematian.

Klien GGK yang menjalani hemodialisis sering mengalami gangguan psikososial, seperti kecemasan, ketidakberdayaan, gangguan peran, identitas personal dan harga diri rendah. Hal ini bisa dipahami karena dengan keadaan sakitnya klien GGK yang menjalani hemodialisa tidak mampu mengatur hidupnya sendiri dan selalu bergantung dengan orang lain bahkan dengan alat yaitu mesin dialisa. Keadaan tersebut juga akan mengganggu hubungannya dengan orang disekitarnya termasuk lingkungan masyarakatnya (Purwanto, 2004).

Klien dengan GGK yang menjalani hemodialisis akan mengalami perubahan pola pikir maupun pola perilaku. Untuk mengantisipasi, klien GGK yang menjalani hemodialisis yang paling tepat adalah dengan diberikan Cognitive Behavior Therapy (CBT). Menurut Bush (2005), yang menyatakan CBT menggabungkan dua jenis psikoterapi yang paling efektif, yaitu terapi kognitif dan terapi perilaku.

Terapi perilaku membantu melemahkan hubungan antara situasi yang menyulitkan dengan reaksi yang biasa ditampilkan. Reaksi tersebut termasuk rasa takut, depresi, atau marah, dan tingkah laku merusak diri. Terapi perilaku juga mengajarkan tentang bagaimana menenangkan pikiran dan tubuh, sehingga dapat merasa lebih baik, berpikiran lebih jernih, dan menyelesaikan masalah atau membuat keputusan yang lebih baik. 
Terapi kognitif mengidentifikasi atau mengenali pemikiran yang negatif dan merusak yang dapat mendorong ke arah rendahnya harga diri yang menetap. Apabila digabungkan ke dalam CBT, dapat menjadi alat yang kuat untuk menghentikan symptom dan membuat hidup lebih bermakna dan memuaskan (Bond \& Dryden, 2002; Bush, 2005). Stallard (2002) menyatakan bahwa tujuan keseluruhan dari CBT adalah untuk meningkatkan kesadaran diri, memfasilitasi pemahaman diri yang lebih baik, dan untuk meningkatkan kontrol diri dengan mengembangkan keterampilan kognitif dan perilaku yang tepat.

CBT membantu untuk mengidentifikasi pikiranpikiran dan kepercayaan yang negatif, bias, dan kritik diri. CBT juga mengajarkan klien untuk meningkatkan harga diri mereka, yaitu dengan cara memahami hubungan antara pikiran, perasaan dan perilaku (apa yang harus dilakukan), dengan mengajarkan klien untuk mengidentifikasi pikiran otomatis negatif, dan mengidentifikasi kesalahan yang mendasari pikiran otomatis negatif.

Perspektif CBT yang menghakimi pikiran dan kritik diri sering menyebabkan masalah terkait dengan harga diri rendah. Misalnya, orang yang memiliki harga diri rendah sering menganggap diri mereka untuk tidak layak bahagia, tidak mampu mengatasi masalah, dan tidak disukai oleh orang lain. Pikiran seperti itu menyebabkan orang-orang tersebut merasa sedih, cemas, dan umumnya tidak bahagia. Kombinasi pikiran dan perasaan seperti itu menyebabkan mereka untuk menghindari kesempatan seperti kegiatan sosial, persahabatan, tantangan, dan pekerjaan tertentu, yang semua ini cenderung membuat mereka menilai dirinya sendiri merasa lebih buruk (Bond \& Dryden, 2002; Bush, 2005).

Terapi yang efektif untuk klien dengan harga diri rendah adalah meningkatkan harga diri orang tersebut. Perbaikan dalam diri yang nyata, adalah Cognitive Behavior Therapy (CBT), yaitu suatu bentuk terapi yang memadukan terapi kognitif dan terapi perilaku. Terapi kognitif mengarahkan cara mereka berpikir tentang diri mereka sendiri, tentang orang lain, dan dunia yang dapat mempengaruhi kesehatan mental mereka. Terapi perilaku mengarahkan cara tindakan mereka yang dapat berpengaruh terhadap interaksi mereka dengan orang lain dan di masyarakat (Stallard, 2002; Bush, 2005; Sulistio, 2006).

Tujuan umum penelitian ini ingin menguraikan pengaruh Cognitive Behavior Therapy (CBT) terhadap perubahan harga diri klien gagal ginjal kronik di unit hemodialisa RS H Jakarta 2011.

\section{Metode}

Penelitian ini menggunakan metode penelitian quasi experimental dengan desain penelitian "Quasi experimental pre-post test without control group" dengan intervensi Cognitive Behavior Therapy (CBT) pada Mei sampai dengan Juni 2011.

Tehnik pengambilan sampel disesuaikan dengan kriteria inklusi yang sudah ditetapkan sebelum penelitian. Penelitian dilakukan untuk menganalisa perubahan harga diri klien gagal ginjal kronik (GGK) di Unit Hemodialisa RS H Jakarta antara sebelum dan sesudah terapi $C B T$. Responden berjumlah 27 orang. Uji statistik yang dipergunakan yaitu bivariat dengan analisis independent t-Test, regresi sederhana, post Hoc test, dan Anova dengan tampilan dalam tabel dan distribusi frekuensi.

\section{Hasil}

\section{Karakteristik Responden}

Hasil analisis karakteristik klien menunjukkan bahwa dari 27 responden dengan reata usia 46,22 tahun, lama sakit dalam bulan reata 25,85 bulan, frekuensi hemodialisis reata 206,78 kali, jenis kelamin responden relatif seimbang antara laki-laki dan perempuan, laki-laki 51,8\%, dan perempuan $48 \%$. Status pekerjaan yang bekerja $55,5 \%$, tidak bekerja $44,4 \%$, dan pendidikan terbanyak tamatan SMU/ SMA 55,5\%. 
Grafik 1. Nilai Rata-Rata Harga Diri Aspek Kognitif dan Perilaku Sebelum dan Sesudah Terapi CBT

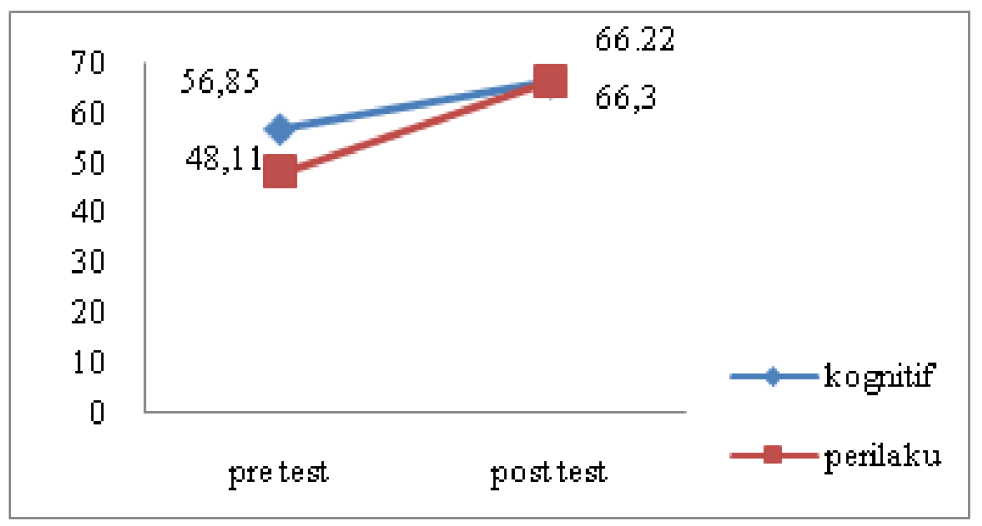

\section{Analisis Harga Diri Klien Sebelum dan Sesudah Diberikan Terapi CBT}

Hasil analisis harga diri sebelum terapi CBT, aspek kognitif; rerata kemampuan kognitifnya 56,85 dengan nilai optimal 80. Aspek perilaku, rerata kemampuan perilakunya 48,11 dengan nilai optimalnya 80. Hasil analisis harga diri setelah terapi CBT aspek kognitif, rerata kemampuan kognitif 66,22, aspek perilaku rerata kemampuan perilakunya 66,30 (lihat pada grafik 1 ).

Hasil analisis pada tabel 1 menunjukkan bahwa terdapat peningkatkan yang signifikan sebesar $11,8 \%$ aspek kognitif dan peningkatan $11,7 \%$ perilaku $(\mathrm{p}=0,000 ; \alpha=0,05)$. Sesuai dengan hasil analisis Paired samples test yang menunjukkan bahwa ada perubahan kemampuan kognitif yang bermakna antara sebelum diberikan terapi CBT dan sesudah diberikan terapi CBT ( $\mathrm{p}=0,000 ; \alpha=0,05)$. Selain itu, hasil analisis pada tabel 2 menunjukkan bahwa terdapat peningkatan $22,7 \%$. Hasil analisis Paired samples Test menunjukkan bahwa ada perubahan kemampuan perilaku yang bermakna antara sebelum diberikan terpi CBT dan sesudah diberikan terapi CBT $(p=0,000 ; \alpha=0,05)$.

\section{Pembahasan}

Klien GGK selama menjalani hemodialisis akan merasa tidak mampu menentukan hidupnya sendiri atau merasa selalu bergantung dengan orang lain, merasa membebani keluarga, tidak mampu menjalankan pekerjaan seperti semula, terganggu perannya di dalam keluarga dan masyarakat. Hal tersebut yang dapat menimbulkan penilaian negatif pada dirinya yaitu tidak berguna, tidak mempunyai harapan dan tidak berharga (Kusnadi, 2003). Klien GGK di unit hemodialisa RS H Jakarta ternyata mempunyai nilai harga diri dari segi kognitif ratarata tinggi, artinya secara kognitif mereka tidak terganggu walaupun hidup dalam ketergantungan dengan alat atau mesin maupun orang lain.

Gejala psikis yang sering diperlihatkan klien dengan harga diri rendah adalah kehilangan rasa percaya diri. Klien harga diri rendah cenderung memandang segala sesuatu dari sisi negatifnya,

Tabel 1. Analisis Tingkat Harga Diri (Kognitif) Klien GGK di Unit Hemodialisa Sebelum dan Sesudah Terapi CBT

\begin{tabular}{|c|c|c|c|c|c|c|}
\hline Karakteristik & Mean & SD & SE & Min-mak & $95 \% \mathrm{CI}$ & $\mathbf{p}$ \\
\hline $\begin{array}{l}\text { Tingkat harga diri aspek } \\
\text { kognitif (sebelum terapi CBT) }\end{array}$ & 56,85 & 5,524 & 1,063 & $47-67$ & 54,67 & 0,000 \\
\hline $\begin{array}{l}\text { Tingkat harga diri aspek } \\
\text { kognitif (setelah terapi CBT) }\end{array}$ & 66,22 & 7,683 & 1,479 & $49-76$ & 63,18 & \\
\hline
\end{tabular}


termasuk menilai diri sendiri. Perasaannya sensitif sekali, sehingga sering peristiwa yang sederhana jadi dipandang dari sudut pandang yang berbeda oleh mereka, atau bahkan disalahartikan oleh mereka. Akibatnya, mereka mudah tersinggung, mudah marah, perasa, curiga akan maksud orang lain (yang sebenarnya tidak ada apa-apa), mudah sedih, murung, dan lebih suka untuk menyendiri. Perasaan bahwa diri tidak berguna ini muncul karena mereka merasa menjadi orang yang gagal (Boyd \& Nihart 1998; Stuart \& Laraia, 2005; Stuart \& Sundeen, 2005).

Perasaan bersalah terkadang timbul dalam pemikiran seseorang yang mengalami harga diri rendah. Klien memandang suatu kejadian yang menimpa dirinya sebagai suatu yang memalukan atau akibat dari kegagalan mereka melaksanakan tanggung jawab yang seharusnya dikerjakan. Banyak pula yang merasa dirinya menjadi beban bagi orang lain dan menyalahkan diri mereka atas situasi tersebut (Boyd \& Nihart 1998; Stuart \& Laraia, 2005; Stuart \& Sundeen, 2005).

Hasil penelitian menyatakan bahwa hampir semua klien merasakan situasi tersebut di atas, dialami klien pada awal-awal terapi hemodialisis namun dengan berjalannya waktu mereka menjadi terbiasa dan akhirnya dirasakan sebagai peristiwa yang biasa saja. Sebagian besar responden mengatakan bahwa sudah sangat 'bersahabat' dengan sisa fungsi ginjalnya yang minimal tersebut. Selain itu, hasil penelitian ini juga menunjukkan bahwa tingkat harga diri klien dengan GGK yang dirawat di unit hemodialisa hanya memiliki hubungan yang kuat dengan pemberian terapi CBT dan tidak memiliki hubungan yang bermakna terhadap karakteristik klien.

\section{Kesimpulan}

Terapi CBT berpengaruh terhadap perubahan harga diri klien GGK di Unit Hemodialisa RS H Jakarta. Harga diri responden meningkat secara bermakna baik dari aspek kognitif maupun dari aspek perilaku setelah diberikan intervensi CBT. Terapi CBT juga berpeluang meningkatkan harga diri aspek kognitif dan berpeluang meningkatkan harga diri dari aspek perilaku setelah dikontrol faktor lain.

Bagi aplikasi keperawatan, terapi CBT dapat dijadikan panduan perawat spesialis jiwa dalam melaksana kan CBT pada klien dengan masalah psikososial. Untuk rumah sakit umum CBT dapat digunakan untuk mengembangkan pelayanan kesehatan jiwa yang terintegrasi dalam pelayanan keperawatan dalam upaya meningkatkan kualitas asuhan keperawatan jiwa, pada klien dengan masalah-masalah psikososial. Perawat spesialis keperawatan jiwa hendaknya menjadikan terapi CBT sebagai salah satu kompetensi yang dapat diberikan pada pelayanan kesahetan jiwa di tatanan pelayanan kesehatan umum.

Penelitian lanjutan perlu dilakukan, yaitu seperti penelitian kualitatif untuk mengkaji lebih dalam terkait dengan masalah-masalah yang dihadapi klien berhubungan dengan dampak penyakit yang dideritanya. Penelitian selanjutnya disarankan untuk menggali peran keluarga terhadap perubahan harga diri klien GGK di unit hemodialisa. Selain itu, perlu diteliti lebih lanjut mengenai faktor perancu lain, seperti contoh lamanya penusukan ke arteri atau vena, lamanya penekanan setelah dialisis, dan pengaruh peningkatan berat badan sebelum dialisa (DN, NN, MK).

Tabel 2. Analisis Tingkat Harga Diri (Perilaku) Klien Sebelum dan Sesudah Terapi CBT

\begin{tabular}{lcccccc}
\hline \multicolumn{1}{c}{ Karakteristik } & Mean & SD & SE & Min-mak & 95\% CI & p \\
\hline $\begin{array}{l}\text { Tingkat harga diri aspek perilaku } \\
\text { (sebelum terapi CB T) }\end{array}$ & 48,11 & 3,203 & 0,616 & $41-53$ & 54,67 & 0,000 \\
$\begin{array}{l}\text { Tingkat harga diri aspek perilaku } \\
\text { (setelah terapi CBT) }\end{array}$ & 66,30 & 7,849 & 1,510 & $48-74$ & 63,19 & \\
\hline
\end{tabular}




\section{Referensi}

Bond, F.W., \& Dryden. (2002). Handbook of cognitive behaviour therapy. Chichester: John Wily \& Sons, Ltd.

Boyd, M.A., \& Nihart, M.A. (1998). Psychiatric nursing: Contemporary practice (1st Ed.). Philadelphia: Lippincott - Raven Publisher.

Bush, J.W. (2005). Cognitive behavior therapy. Diperoleh dari http://www.cognitivetherapy. com/index.html.

Depkes RI. (2004). Angka kejadian penyakitpenyakit kronik di Indonesia. Jakarta: Direktorat Jenderal Bina Pelayanan Medik Departemen Kesehatan RI.

Feldman. (1989). Adjustment: Applying psychology in complex world. New York: Mc Graw-Hill.

Kusnadi, Y. (2003). Depresi pada pasien gagal ginjal. Diperoleh dari http://www.indomedia. com/stripo/2003/10/19/1910kes2.htm.

Levey, A.S., \& Coresh, J. (2001). Clinical practice guidelines for chronic kidney disease: Evaluation, classification, and stratification. AJKD, 39 (2), S1-S266.

Lumenta, N.A. (2005). Konsultasi: Mencegah gagal ginjal. Diperoleh dari http://www.sinarharapan. co.id/iptek/kesehatan/2005/0506/kes2.html.
Purwanto. (2004). Dapatkah gagal ginjal bertahan hidup. Diperoleh dari http://www.suaramerdeka. com/harian/0406/08/kol05.htm.

Roesli, R.M.A. (2006). Gagal ginjal. Diperoleh dari http://totalwellness.blogsome.com/.

Siregar, P. (2001). Paradigma baru penatalaksanaan gagal ginjal terminal. Diperoleh dari http:// www.tempo.co.id/medika/arsip/022002/keg1.htm.

Stallard, P. (2002). Think good - feel good: A cognitive behavior therapy workbook for children and young people. Chicester. John Wiley \& Sons.

Stuart, G.W., \& Laraia, M.T. (2005). Principle and practice of psychiatric nursing (8th Ed.). Philadelphia: Elsevier Mosby.

Stuart, G.W., \& Sudeen, S.J. (2005). Buku saku keperawatan jiwa (4th Ed.). Jakarta: EGC.

Suhud, M. (2005). Cuci darah demi kualitas hidup. Diperoleh dari http://kompas.com/ kesehatan/news/0508/21/080710.htm.

Sulistio, A. (2006). Cognitive behavior therapy untuk anak dengan konsep diri negatif. Jakarta: Fakultas Psikologi UI. 